\title{
Two new species of Dillwynia (Fabaceae: Mirbelieae) from the Southern Tablelands of New South Wales
}

\author{
Peter C. Jobson and Peter H. Weston
}

\begin{abstract}
Jobson, Peter C. ${ }^{1,2}$ and Weston, Peter H. ${ }^{1}$ ('National Herbarium of New South Wales, Royal Botanic Gardens, Sydney, NSW 2000, Australia; 'Dept. of Environmental Sciences, University of Technology, Sydney, Gore Hill, NSW 2065, Australia)1999. Two new species of Dillwynia (Fabaceae: Mirbelieae) from the Southern Tablelands of New South Wales. Telopea 8(3) 363-369. Dillwynia crispii Jobson \& P.H. Weston and D. palustris Jobson \& P.H. Weston, two new species from the Southern Tablelands of New South Wales, are described along with their ecology, distribution and conservation status. Their affinities with closely related species are also discussed.
\end{abstract}

\section{Introduction}

As a result of our continuing revisionary research into the systematics of Dillwynia for Flora of Australia, these two species are here described. One species, Dillwynia crispii Jobson \& P.H. Weston, has been recognised informally for the last thirty years as a distinct species and for the Flora of New South Wales treatment (Weston 1991) was called 'Dillwynia species $C^{\prime}$. The other species was first collected in 1962 and has been referred to as 'sp. aff. D. retorta' or 'D. retorta (prostrate form)' by various collectors. We have examined both species in the wild and were able to make valuable observations of their habit and preferred habitat. We describe these new species below, along with their distribution and ecology, and assess their conservation status. We also compare them with species that appear to be their closest relatives. An updated key to all the known species of Dillwynia in New South Wales is currently being written for the forthcoming second edition of Volume Two the Flora of New South Wales.

\section{Taxonomy}

Dillwynia crispii Jobson $\mathcal{E}$ P.H. Weston, sp. nov.

Frutex erectus ramificans usque ad $2.5 \mathrm{~m}$ altus; caules glabri vel pilis appressis sericei, cicatricibus foliorum decurrentibus prominentibusque; folia triquetra vel semiteretia, suberecta, glabra; inflorescentia axillaris, biflora, in axillis superis fasciculata; calyx glaber; fructus pubescentes, rubiginosi.

Holotype: New South Wales: Southern Tablelands: Just N of Bulee Gap, (c. $2.5 \mathrm{~km}$ E of Endrick River crossing) $8.8 \mathrm{~km}$ NE of Nerriga, 350. $5^{\prime} 43^{\prime \prime} \mathrm{S} 150^{\circ} 08^{\prime} 11^{\prime \prime E}$, P.C. Jobson 5123 $\mathcal{E}$ P.H. Weston, 20 Oct 1997 (NSW 426807). Isotypes: A, AD, B, BRI, CANB, CHR, E, HO, K, MEL, MO, NY, P, PRE, S.

[Dillwynia sp. C. in Weston (1991)]

Erect, single-stemmed shrub 0.6-2.5 m high. Bark smooth, red-brown becoming grey with age, with olive, minutely colliculate flanges (the remnants of the persistent decurrent leaf bases). Branches and branchlets longitudinally ridged, alternating 
brown and olive; brown ridges with antrorse, appressed white hairs c. $0.5 \mathrm{~mm}$ long; olive ridges glabrous, minutely colliculate. Leaves spreading to loosely antrorseappressed, linear, triquetrous to semiterete, glabrous, minutely colliculate; young leaves lime green; petiole c. $1 \mathrm{~mm}$ long, decurrent leaf bases yellow-green, 0.5-3.0 mm long, colliculate; lamina with a longitudinal adaxial groove, occasionally slightly twisted, 1.0-2.2 cm long, 0.75-1.25 mm wide, apex mucronate, often with an incurved tip; stipules present, yellow, brown and scarious with age, 0.1-0.5 mm long. Inflorescences axillary, clustered in upper axils, 2-flowered. Peduncles 1.0-2.5 mm long. Bracts ovate to narrow-ovate, $1.5-2.5 \mathrm{~mm}$ long, entire, cucullate, yellow, ciliate with white hairs in upper portion of margin; bracteoles ovate, 1.0-2.0 $\mathrm{mm}$ long, entire, yellow to red-brown, ciliate with white, straight hairs, chiefly on upper portion of margin but occasionally along the entire margin, rarely glabrous, attached to pedicel 0.5-2.0 mm below calyx tube. Buds rosy pink to red-brown with the lobes occasionally olive green; upper calyx lobes cucullate. Calyx faintly 10-ribbed, rosy pink to redbrown, glabrous, 4.5-7.0 mm long; calyx tube turbinate; lobes shorter than tube; lower lobes broadly acute; upper lobes v-shaped notched, divergent, margins ciliate with white crisped hairs. Standard with basal oblong claw and lamina reniform with a deep v-notch separating the lobes; lamina 5.5-7.0 mm long, 10.5-15.0 mm wide; lobes obovate, yellow with broad red band (crescent) above claw; claw yellow, 4.0-5.0 mm long, 1.5-2.25 mm wide. Wings narrow-obovate to oblong, partially obscuring keel, parallel, obtuse, yellow at apex grading to rosy pink mid way to base; lamina 7.5-9.0 mm long, 2.5-3.5 mm wide; claw 1.5-2.0 mm long, 1.0-1.5 mm wide. Keel ovate when viewed from above, oblong in lateral view, with apex open and divergent, obtuse, rosy pink to red with faint green markings towards centre, $6.5-7.5 \mathrm{~mm}$ long, $2.0-2.5 \mathrm{~mm}$ wide; upper margin papillate to minutely ciliate; claw c. $2 \mathrm{~mm}$ long. Stamens articulated onto a basal ring c. $2 \mathrm{~mm}$ long, filaments 3.5-5.0 mm long; anthers $0.5-1.0 \mathrm{~mm}$ long. Gynoecium 4.0-6.0 mm long; ovary white-pubescent, 1.5-2.0 mm long; stipe glabrous c. $0.5 \mathrm{~mm}$ long; style hooked, glabrous, c. $2 \mathrm{~mm}$ long; stigma conical. Pod ovoid, turgid, red-brown, pubescent with scattered white hairs, occasionally glabrescent towards centre, $6.0-7.5 \mathrm{~mm}$ long, $4.0-5.0 \mathrm{~mm}$ wide; petals caducous during late development of pod. Seeds ovoid to reniform, c. $2.5 \mathrm{~mm}$ long, smooth, brown-red to dark brown; aril cream-yellow. (Fig. 1).

Phenology: flowers chiefly in October but occasionally in late September and early November; fruits in late December to early January.

Distribution: known only from the northern Budawang Ranges between Nerriga and Sassafras, New South Wales. (Fig. 3).

Habitat: in dry sclerophyll woodland dominated by Eucalyptus sieberi, E. dendromorpha and occasionally E. agglomerata with a dense shrubby understorey on shallow gravelly sand, and in crevices on rocky sandstone pavements. It is usually found on the edge of escarpments and exposed cliff tops. The altitudinal range of this species is between $750 \mathrm{~m}$ and $850 \mathrm{~m}$.

Conservation Status: the known distribution of this species is almost completely within the confines of the Morton National Park, much of which has recently been given Wilderness status, so it is protected. However, because of its narrow distribution it should be coded 2RC according to the criteria of Briggs and Leigh (1996).

Etymology: the epithet crispii honours Dr Michael D. Crisp from the Australian National University in Canberra, who has greatly advanced our knowledge of the systematics of the tribe Mirbelieae.

Notes: Dillwynia crispii was first collected by William Baeuerlen in 1886 in the 'Braidwood District' but it was not until the early 1960s, when the road between Nowra and Nerriga was upgraded, that extensive collections of this species were 
made. However, the extent of the species' distribution is still poorly known due to the rugged and inaccessible nature of the region. For example, surveying within the army reserve adjoining the eastern side of the Sassafras portion of Morton National Park might conceivably extend the known distribution. The Baeuerlen collecting locality is vague and it should not be assumed that the species grows as far south as Braidwood, especially since, in the last 30 years of increased collecting in the area, the species has been found no further south than Quiltys Mountain, southeast of Nerriga.

This species closely resembles D. stipulifera Blakely (Weston 1991) and in the past was also misidentified by collectors as a form of D. acicularis Sieber ex DC. Dillwynia crispii and $D$. stipulifera are the only two species in the genus known to possess more than vestigial stipules. They can be separated, however, using the following characters: $D$. crispii is a robust erect shrub to $2 \mathrm{~m}$ whereas $D$. stipulifera is a decumbent filiform shrub to $0.5 \mathrm{~m}$ with the leaves tending to be more keeled and less crowded. They also have distinctly different habitat requirements: $D$. stipulifera prefers swampy to swampy-heath communities whereas $D$. crispii prefers dry sclerophyll woodlands on exposed cliff tops and escarpments. Dillwynia acicularis differs from D. crispii in having a terminal inflorescence, campanulate calyx tube, persistent corolla in fruit, smaller
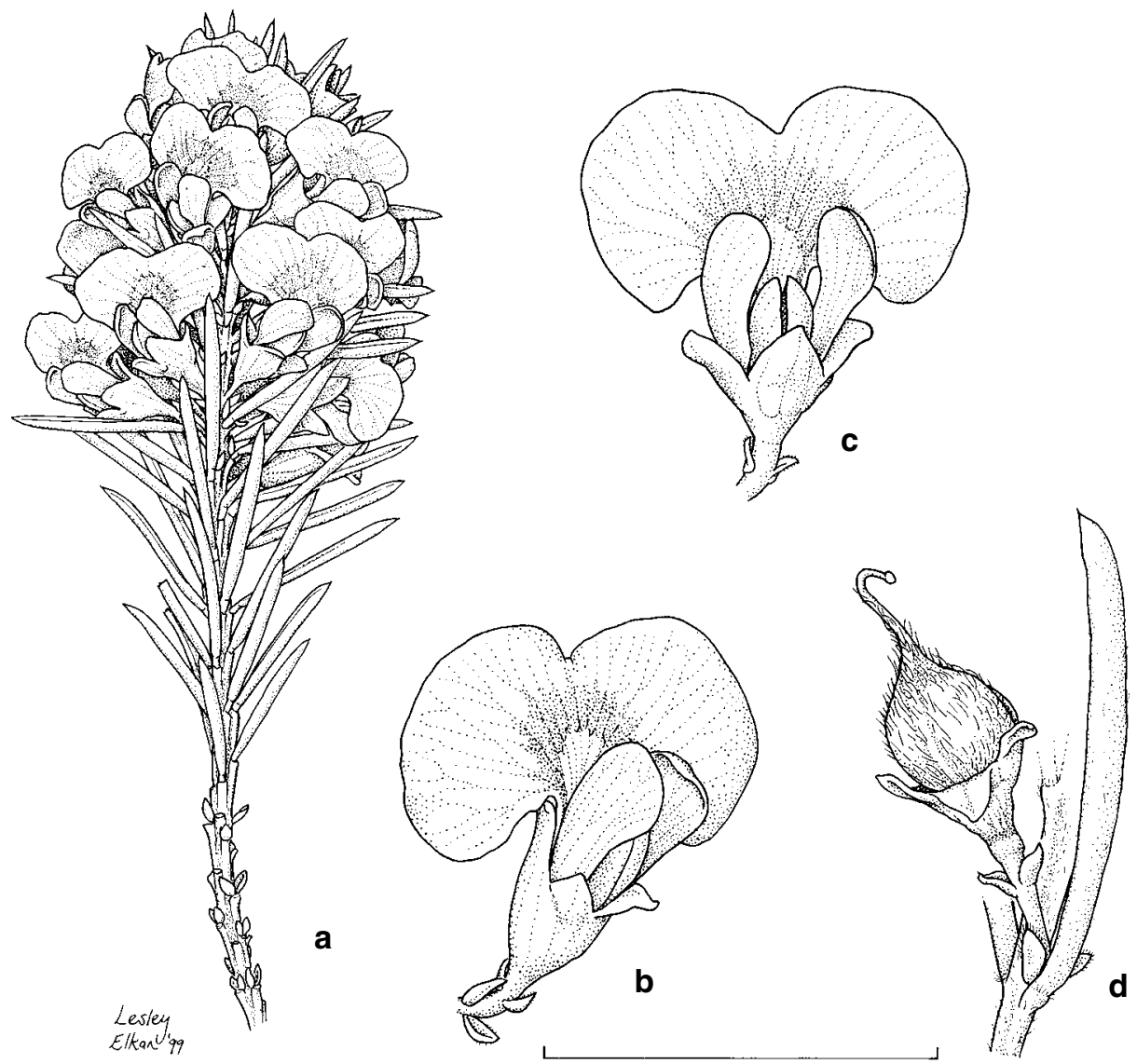

Fig. 1. Dillwynia crispii. $\mathbf{a}$, habit; $\mathbf{b}$, side view of flower; $\mathbf{c}$, front view of flower; $\mathbf{d}$, pod (a-c from Jobson 5123 \& Weston; d from Ingwerson s.n. (CBG 7708347)). Scale bars: $\mathrm{a}=3 \mathrm{~cm} ; \mathrm{b}, \mathrm{c}=1.5 \mathrm{~cm} ; \mathrm{d}=1 \mathrm{~cm}$ 
flowers (eg. standard lamina 7-9 mm wide), leaves with a distinct pungent point and stems covered in a white indumentum.

Selected specimens examined: New South Wales: Southern Tablelands: Nowra Rd 4 miles [6.4 km] E of Nerriga, 3506'S 150¹0'E, Adams 1454, 13 Oct 1965 (fl.)(CANB, A, AD, B, BM, BH, BRI, E, G, K, L, MEL, NSW, NT, NY, NZ, P, US); edge of sandstone plateau, E of Endrick River, Pullen 872, 25 Jun 1958 (old fr.) (CANB, NSW); Sassafras Rd, 5 miles [8.1 km] from Nerriga, Shoobridge s.n., 28 Oct 1962 (fl.) (CBG 013066); The Jumps, on Touga Rd, NNE of Nerriga, 3501'39"S 15008'20"E, Jobson 5128 \& Weston, 20 Oct 1997 (fl.)(NSW, BRI, MEL), M. McMillan 72/80, 11 Dec 1972 (fr.)(CANB); Pigeon House Ridge, Burgess s.n., 13 Oct 1962 (fl.) (NSW 63224, CANB); The Vines, Endrick State Forest, S of Sassafras, 35¹2'S 150¹1'E, Constable 171, 29 Oct 1957 (fl.)(NSW, CANB); top of Quiltys Mountain, near Bora Ground, Budawang Range, 35¹0'S 150¹0'E, D. Black s.n., 6 Nov 1981 (fl.) (NSW 419979); Braidwood district, Baeuerlen 112, Nov 1886 (MEL — 2 sheets).

\section{Dillwynia palustris Jobson \& P.H. Weston, sp. nov.}

Frutex infirme ascendens vel decumbens, aliquando tegetem formans, in caulibus veteribus radicans; caules cum pilis retrorsis vestiti; folia torta, glabra vel pilis sparsis aliquando instructa; inflorescentia terminalis lateralisque, in pedunculis usque ad 28 mm longis; calyx glaber; fructus pubescentes, fuliginosi.

Holotype: New South Wales: Southern Tablelands: N side of Bullongra Rd (c. $1 \mathrm{~km}$ E of Preston Rd junction), $27.7 \mathrm{~km}$ ENE of Tumbarumba in Bago State Forest, 3541'35"S 14809'48"E, P.C. Jobson 5473 E P.H. Weston, 22 Jan 1998 (NSW 430319). Isotypes: BRI, CANB, $\mathrm{HO}, \mathrm{K}, \mathrm{MEL}, \mathrm{MO}, \mathrm{NBG}$.

Weakly ascending to decumbent shrub, 0.1-0.5 $\mathrm{m}$ high, $0.3-0.5 \mathrm{~m}$ wide, occasionally forming mats to $1.5 \mathrm{~m}$ diameter; older, subterranean stems often rooting, presence of lignotuber unknown. Bark minutely fissured, red-brown to light brown with an irregular outer charcoal grey to black (occasionally silver) layer, occasionally with white retrorse hairs, lenticels absent. Branches smooth, red-brown to light brown with retrorse to retrorse-appressed minute white hairs. Branchlets yellow to cream, otherwise similar to branches. Leaves spreading, linear, trigonous to flattened, glabrous, occasionally with hairs at the apex, minutely colliculate and often wrinkled when dried, young leaves green, occasionally with scattered white hairs along lamina; petiole $0.25-0.75 \mathrm{~mm}$ long, raised leaf bases yellow, $0.1-0.5 \mathrm{~mm}$, colliculate; lamina chiefly twisted to $90^{\circ}$ but sometimes straight, with a longitudinal adaxial groove, keeled, 2.5-5.0 mm long, 0.25-0.5 mm wide; apex mucronate, acute or obtuse, tip either straight or incurved; stipules present, persistent, yellow, brown and scarious with age, c. $0.25 \mathrm{~mm}$ long. Inflorescence terminal and lateral, 1 to many inflorescences at end of branchlet, 1- to 3-flowered. Peduncles (0.9-)1.1-2.1(-2.8) cm long, glabrous; pedicels $0.9-2.5 \mathrm{~mm}$ long, glabrous. Bracts narrow ovate to lanceolate, $0.75-1.25 \mathrm{~mm}$ long, entire, cymbicate, yellow, obtuse, ciliate with white hairs along margin, denser towards apex; bracteoles narrow ovate to lanceolate, 0.75-1.25 mm long, entire, frequently conduplicate, yellow, acute to acuminate, sparsely ciliate with white hairs, chiefly on upper portion of margin, rarely glabrous, occasionally one red gland present on upper portion of margin, attached to pedicel $0.5-1.0 \mathrm{~mm}$ below calyx tube. Buds pale green, glabrous, cucullate upper calyx lobes. Calyx 10-ribbed, 5 (alternate) ribs terminating near calyx lobe apex, green, glabrous, 3.5-4.5 $\mathrm{mm}$ long; calyx tube turbinate; lobes shorter than tube, lower lobes broadly triangular, upper lobes $\mathrm{v}$-shaped, notched, strongly divergent, margins ciliate with white crisped hairs. Standard with basal oblong claw and lamina broad reniform to broad ovate, strongly concave, shallowly emarginate separating the two lobes; lamina $3.5-4.5 \mathrm{~mm}$ long, 8.0-9.5 mm wide; lobes obovate to circular, orange-yellow with narrow (rarely broad) red band (crescent) above claw; claw yellow to yellow-green, 2.0-3.0 mm long, c. $1 \mathrm{~mm}$ wide. Wings oblong, obscuring keel, imbricate at apex, orange-yellow, sometimes grading to red at base, lamina $4.0-5.0 \mathrm{~mm}$ long, c. $2 \mathrm{~mm}$ wide; claw c. $1 \mathrm{~mm}$ long, 
$0.5-0.75 \mathrm{~mm}$ wide. Keel ovate viewed from above, oblong in lateral view, with apex open and divergent, obtuse, crimson, sometimes grading to green at base, $3.5-4.0 \mathrm{~mm}$ long, c. $1 \mathrm{~mm}$ wide; upper margin smooth to minutely papillate; claw $1.5-2.0 \mathrm{~mm}$ long. Stamens articulated onto a basal ring c. $1 \mathrm{~mm}$ long, filaments $1.0-4.0 \mathrm{~mm}$ long; anthers c. $0.5 \mathrm{~mm}$ long. Gynoecium 3.0-4.0 mm long; ovary white pubescent, 1.0-1.5 mm long; stipe glabrous c. $0.5 \mathrm{~mm}$ long; style hooked, sparsely hairy, c. $2 \mathrm{~mm}$ long, stigma capitate. Pod ovoid, turgid, purple-green turning black-brown with age, pubescent with scattered white hairs (denser towards base of pod), $4.5-5.5 \mathrm{~mm}$ long, $2.5-3.5 \mathrm{~mm}$ wide, on elongated peduncles to $3.0 \mathrm{~cm}$ long; petals caducous during late development of pod. Seeds ovoid to reniform, smooth, dark olive-brown to brown; aril cream-yellow, c. 2 mm long. (Fig. 2).

Phenology: flowers in January to early February; fruits known from late January.

Distribution: known from three areas on the ranges to the east and west of the upper Tumut River catchment, viz. Bago State Forest to the east of Tumbarumba, Bogong Range to the east of Talbingo, and on the plateau from Little Peppercorn Plain northwards towards Brindabella, New South Wales. (Fig. 3). The Bogong Range and Little Peppercorn Plain are both within the Kosciuszko National Park.

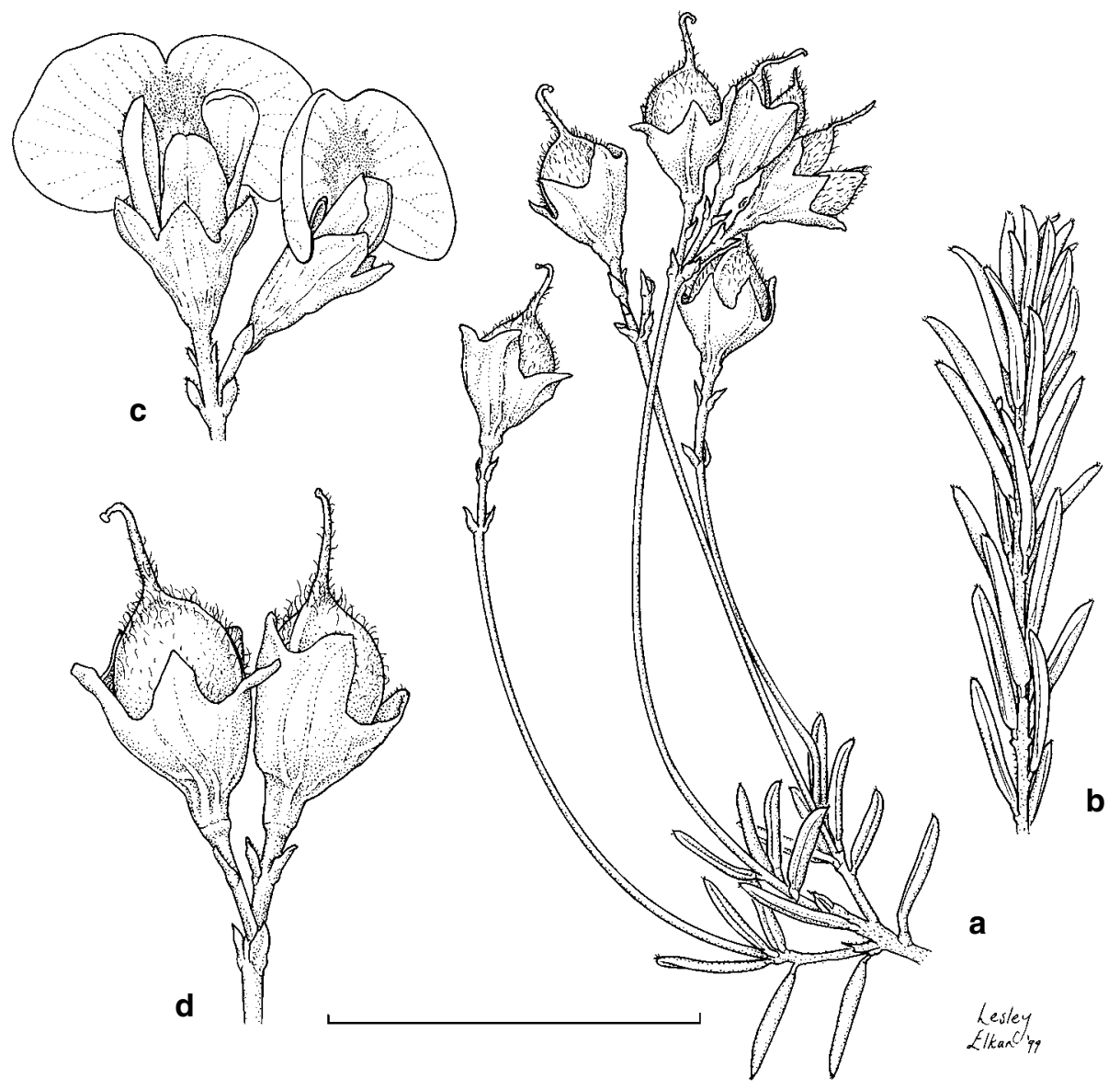

Fig. 2. Dillwynia palustris. a, habit; b, branch; c, inflorescence; $\mathbf{d}$, pod (all from Jobson $5448 \mathcal{E}$ Weston). Scale bars: $\mathrm{a}=1.2 \mathrm{~cm} ; \mathrm{b} \& \mathrm{c}=1 \mathrm{~cm} ; \mathrm{d}=0.66 \mathrm{~cm}$. 
Habitat: Dillwynia palustris occurs along a very narrow ecotone between open Eucalyptus pauciflora-E. stellulata woodlands with grassy understories and Sphagnum-Leptospermum-dominated peaty swamps with permanent water. The species associated with D. palustris in this ecotone include Epacris breviflora, E. microphylla var. microphylla, Poa costiniana, Baeckea gunniana, Baloskion australe, Juncus alexandri var. alexandri, Brachyscome scapigera, Asperula pusilla, Hypoxis hygrometrica var. hygrometrica, Stylidium graminifolium and Aciphylla simplicifolia. The Little Peppercorn Plain population occurred not only along the banks of the swampy creek in a typical habitat as described above, it also occurred on the nearby open low heathy meadow. This heathy meadow had widely spaced Ozothamnus hookeri-Hakea microphylla-Epacris sp. shrubs with a herb stratum dominated by Poa fawcettiae, Leptorhynchos squamatus subsp. 'alpinus', Craspedia variabilis, Poranthera microphylla, Stylidium graminifolium, Rhodanthe anthemoides, Microseris lanceolata, Bracteantha subundulata, Senecio quadridentatus and Brachyscome spathulata.

Conservation Status: three of the known populations of this species occur within the Kosciuszko National Park and so it appears to be adequately conserved. However, because of its narrow distribution pattern and specialised habitat, its conservation coding (Briggs \& Leigh 1996) should be 2VC. No collections have been made from the southern part of the Tumut River catchment (Toolong Range), despite the existence of apparently suitable habitats there. This region has limited access; if plants were located from this area, then the coding would change to $3 \mathrm{VC}$.

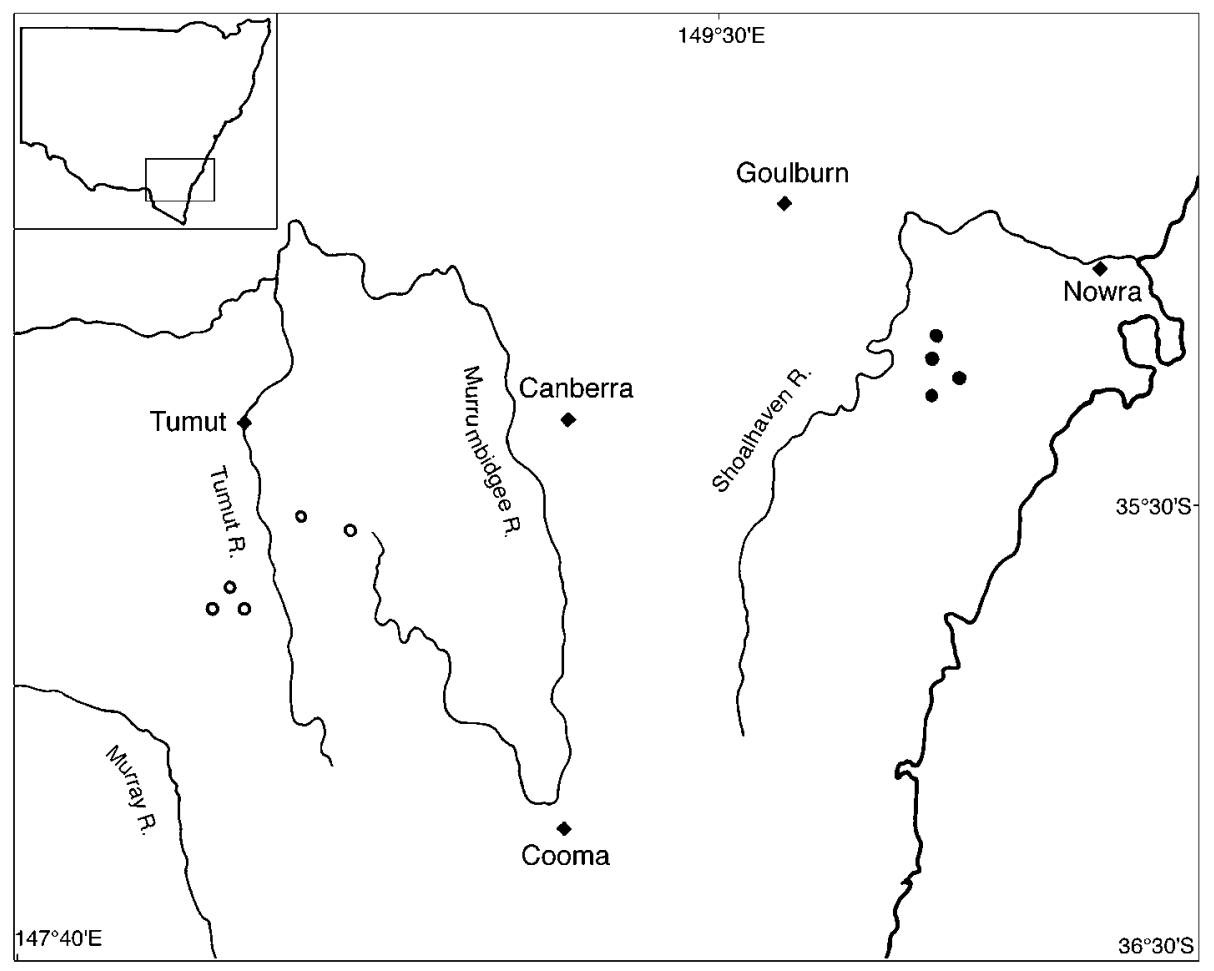

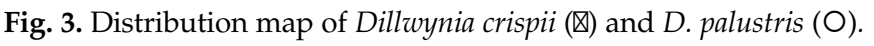


Although the species is conserved within a national park, most populations occur in the Bago State Forest, in which grazing is currently permitted. Dillwynia palustris was absent from swamps that appeared to have experienced heavy grazing. These swamps invariably had heavy infestations of introduced weedy species and appeared to have experienced a drop in the level of the water table. We have observed (Jobson \& Weston 1998) that other species of Dillwynia may be heavily grazed by stock. So the combination of introduction of weedy species, changes in water table and probable palatability to stock are likely to affect the viability of this species over time.

Etymology: the epithet palustris is from the Latin meaning marshy and refers to the preferred habitat of this species.

Notes: this species is part of the D. retorta-phylicoides species complex. Dillwynia palustris has twisted leaves and long peduncles, resembling most closely D. parvifolia R.Br. var. trichopoda Blakely, but differs in its habit, its rooting along the prostrate stems, its bract morphology and its habitat preference. Dillwynia parvifolia var. trichopoda, although still weakly ascending, tends to be more shrub-like in its appearance, its bracts have conspicuous red glands along the margins and it prefers dry sclerophyll woodlands and sandy soils.

Selected specimens examined: (total 13 specimens) New South Wales: Southern Tablelands: near Brindabella, high southern plateau, Gittins 448, Jan 1962 (fl.)(NSW); Little Peppercorn Plain, 23.4 km N of Rules Point, Kosciuszko National Park, 35³3'24"S 148 37'11"E, Taylor 1313, Jackson E Hadlow, 4 Feb 1981 (fl.)(CANB), Jobson 5412 \& Weston, 21 Jan 1997 (fl., fr.)(NSW, AD, BRI, CHR, K, MEL, MO); Bogong Range, 35³3'S 148 26'E, Brooker 5536, 4 Feb 1977 (fl.)(CANB); Western extreme end of Tomney's Plain swamp (near where Tomney's Plain Creek feeds into swamp) $4.0 \mathrm{~km} \mathrm{~N}$ along Powerline Road from Elliot Way turnoff, 3545'00"S 148²14'20"E, Jobson 5478 \& Weston, 22 Jan 1997 (fl.) (NSW, CANB); c. $1 \mathrm{~km} \mathrm{~S}$ from northern end of Spencers Creek swamp, c. $24.5 \mathrm{~km}$ NE of Tumbarumba in Bago State Forest, 3542'47"S 148 08'36"E, Jobson 5470 \& Weston, 22 Jan 1997 (fl., fr.)(NSW, MEL); swamp on Paddys River headwaters, $25.7 \mathrm{~km}$ NE of Tumbarumba in Bago State Forest, 3541'28"S 14808'41"E, Jobson 5448 \& Weston, 22 Jan 1997 (fl.) (NSW, AD, B, CANB, MEL, NY, PRE); near Batlow, Bago State Forest, 35³2'S 14805'E, K. Giles 6, Jan 1964 (fl.) (NSW, CANB).

\section{Acknowledgments}

Peter Wilson checked the Latin diagnoses and Lesley Elkan drew the illustrations and assisted in preparing the map. This project is funded by an Australian Biological Resources Study Research Grant.

\section{References}

Briggs, J.D. \& Leigh, J.H. (1996) Rare and Threatened Australian Plants, 1995 revised edition (CSIRO: Collingwood).

Jobson, P.C. \& P.H. Weston (1998) Dillwynia glaucula ((Fabaceae: Mirbelieae), a new species from the Southern Tablelands, New South Wales. Telopea 8: 1-6.

Weston, P.H. (1991) Dillwynia. Pp.499-504 in Harden, G.J. (ed.) Flora of New South Wales, vol. 2. (New South Wales University Press: Kensington).

Manuscript received 2 July 1999

Manuscript accepted 28 October 1999 
